\title{
CHARACTERISTICS OF FISHBALL ON VARIOUS CONCENTRATION OF CARRAGEENAN FROM DIFFERENT HARVEST TIME OF KAPPAPHYCUS ALVAREZII
}

\author{
ANDI NOOR ASIKIN ${ }^{1 *}$, INDRATI KUSUMANINGRUM ${ }^{1}$, TAUFIK HIDAYAT ${ }^{2}$ \\ ${ }^{1}$ Fishery Product Technology of Fishery and Marine Science, Mulawarman University, Samarinda, East Kalimantan, Indonesia. ${ }^{2}$ Center of \\ Agroindustry Technology, Agency for Assessment and Application Technology, Jakarta, Indonesia. Email: asikin63@yahoo.com
}

Received: 19 February 2020, Revised and Accepted: 03 April 2020

\section{ABSTRACT}

Objective: This paper investigates the effect of carrageenan from various harvest times on fishball characteristics. The harvest time consists of three different periods ( 40 days, 45 days, and 50 days) from Bontang Coastal, East Kalimantan, Indonesia.

Methods: The carrageenan fortified to fishball used two concentrations that were $0.25 \%$ and $0.5 \%$.The proximate analysis, including moisture, ash, protein, fat, and carbohydrate, showed significantly different $(\mathrm{p}<0.05)$. The texture analysis showed that there was significantly different $(\mathrm{p}>0.05)$.

Results: The fishball adding carrageenan from different harvest time of seaweed also had a significantly different of sulfate content and crude fiber content $(\mathrm{p}<0.05)$. The lowest water activity obtained on the fishballs adding $0.25 \%$ carrageenan from 50 days ages harvested.

Conclusions: In this research, the fishball adding 0.25 carrageenan from 50 days ages was the best treatments based on the highest of protein content and the lowest of water activity.

Keywords: Fishball, Harvest time, Kappa carrageenan, Properties.

(c) 2020 The Authors. Published by Innovare Academic Sciences Pvt Ltd. This is an open access article under the CC BY license (http://creativecommons. org/licenses/by/4. 0/) DOI: http://dx.doi.org/10.22159/ajpcr.2020.v13i6.37196

\section{INTRODUCTION}

Carrageenan is one of the red seaweed types which used in many applications, both in food and non-food industry. The application of carrageenan such as thickening agents, gelling agents and stabilizing agents, emulsifying properties, pharmaceutical formulation, cosmetics and other industrial applications [1,2]. Indonesia is one of the countries with the longest beach length in the world has huge potential production of seaweed. Eucheuma cottonii (Kappaphycus alvarezii) is one of the types of seaweed produced in Indonesia [3].

Carrageenan is a linear sulfated galactans can extract from many species of red algae. It is formed by alternate units of D-galactose and 3,6-anhydro-galactose $(3,6-\mathrm{AG})$ joined by $\alpha-1,3$ and $\beta$-1,4-glicosidic linkage. The properties of carrageenan influenced by the number and position of ester sulfate (ES) groups as well as the content of 3,6-AG. Higher levels of ES mean lower solubility temperature and lower gel strength [1].

The properties of carrageenan affected by pre-extraction treatment, extraction methods, solvent, process conditions, and species [4-6]. The properties of carrageenan were also affected by the age of seaweed. Yield and gel strength of carrageenan varies with the age of the crop of seaweed [7]. The characteristics of carrageenan depend on the proper harvest time of seaweed. The range of harvest time between 30 and 60 days resulted the different properties such as yield, moisture content, viscosity, and gel strength [8].

The carrageenan application on food has been the subject of numerous studies, such as the effect of carrageenan on the functional characteristics of meat product such as meat sausage properties. Carrageenan addition at low levels $(0.2 \%$ and $0.5 \%)$ increase gel elasticity. However, a higher carrageenan concentration caused a reduction in sausage elasticity [9]. The addition of up to $2 \%$ carrageenan to myofibril protein was not significantly effective in thermal transition temperature and caused by negligible changes in thermal stability. Increasing the carrageenan level in mixture negatively affected the expressible fluid, cohesiveness, and springiness [10]. Carrageenan gel texture depends on the type used and method of production, as well as the $\mathrm{pH}$ value of the solution. The addition of carrageenan to low-fat meat batters improved the quality of the frankfurters, especially the texture results and sensorial analyses [11]. Carrageenan as edible coatings slows down the decay of the physicochemical characteristics of fresh fillets [12]

Previously, numerous studies have been carried out on the method of carrageenan extraction and carrageenan application, but the existing literature on harvest time in relation to carrageenan properties and application is still limited. Therefore, the aim of this study was to evaluate the effect of various concentrations of carrageenan extracted from different harvest time of seaweed on fishball properties. The fishball characteristics, including proximate analyses, crude fiber content, sulfate content, texture, water activity, and color.

\section{MATERIALS AND METHODS}

Materials

K. alvarezii was harvested from Bontang Coastal, East Kalimantan, Indonesia, from different harvest time (40, 45, and 50 days). Mackerel fish, tapioca flour, and condiments were bought from the local market (East Kalimantan, Indonesia). Kalium hydroxide (Merck), Kalium chloride (Merck), Isopropyl alcohol (Merck) were purchased from Chemmix Pratama Laboratory, Yogyakarta, Indonesia.

\section{Carrageenan extraction}

Dried seaweed was washed with tap water to remove salt and other compounds. Extraction of carrageenan was done according to Asikin and Kusumaningrum [8] and Asikin et al. [13]. Dried seaweed was weighed $40 \mathrm{~g}$ then soaked in the water for $3 \mathrm{~h}$, subsequently rinsed and drained. The solvent used $\mathrm{KOH} 7 \%$ was heated until reached $70^{\circ} \mathrm{C}$, then the seaweed boiled for about $30 \mathrm{~min}$. After that, the seaweed was washed 3 times and then reheated $\left(70^{\circ} \mathrm{C}\right)$ using distillate water for $3 \mathrm{~h}$. The sample was filtration with cheese clothes. The filtrate was 
precipitated by adding $\mathrm{KCl}$ and iso-propanol with stirring gently until homogenous and it was left for overnight. The next step was filtration with cheese clothes. The substrates obtained were collected and oven dried at $60^{\circ} \mathrm{C}$ for $24 \mathrm{~h}$. The dried carrageenan sheets were ground to obtain carrageenan flour.

\section{Minced fish preparation}

The fish were de-headed, gutted, and washed in tap water. The dressed fish was filleted to separate from the skin and the bone. The fillet was washed with chilled water $\left(5^{\circ} \mathrm{C}\right)$. The clean fillet was minced using a food processor (Phillips) by adding ice to produce minced fish. The minced fish was put in polyethylene bags and stored at chiller until required.

\section{Fishball preparation}

The minced fish were mixed various ingredients, including $10 \%$ starch, $2 \%$ salt, $0.5 \%$ pepper, and $0.5 \%$ garlic. The carrageenan was added into mixed mince with two concentrations as treatments: $0.25 \%$ and $0.5 \%$. All ingredients were mixed until homogeneous to make dough. The dough was shaped into balls. The fishball was boiled for about $15 \mathrm{~min}$ and then dipped in ice water for $5 \mathrm{~min}$. The fishball was stored in the freezer before analyses.

\section{Chemical analyses}

The moisture content was estimated by the AOAC method [14]. Samples were dried at $105^{\circ} \mathrm{C}$ an oven until they reached a constant weight. The moisture content was estimated based on the weight loss between before and after drying. Ash content was determined using dry ashing procedures [14]. Crude protein was determined by Kjeldahl method [14]. Fat content was estimated by Soxhlet extraction. Carbohydrate content was calculated by difference. Crude fiber and sulfate content were estimated following procedures of Apriyantono [15]. The texture was estimated by texture analyzer (TA). TA was used to penetrate the approximate $2 \mathrm{~cm}$ diameter fishballs. Water activity (aw) was determined using a water activity meter. Color was measured with a colorimeter at three locations for $L^{*}$, $a^{*}$, and $b^{*}$ values. $L^{*}$ represents the total light reflected on a scale ranging from $0=$ black to $100=$ white. $\mathrm{a}^{*}$ represents the amount of red (positive values) and green (negative values), while $\mathrm{b}^{*}$ values represent the amount of yellow (positive values) and blue (negative values)

\section{Statistical analysis}

Data of the experiment were analyzed by a completely randomized design with six treatments. The means of all the parameters were measured for significance by one-way analysis of variance. The significant effect was accomplished by Duncan's test at a $95 \%$ significance level.

\section{RESULTS}

\section{Proximate analysis}

The proximate analysis of fishball samples is presented in Table 1 as compared to the fishball without carrageenan, with sodium tripolyphosphate (STPP) addition and Indonesian Standard (SNI No. 7266:2014) [16]. The moisture content of fishball varied from $75.66 \%$ to $77.89 \%$. The result showed that the moisture content of fishball added $0.25 \%$ carrageenan made from 40 days age was showed a significant difference $(\mathrm{p}<0.05)$ with $0.5 \%$ and both of concentration from 50 days ages of seaweed.

The ash content of the fishball resulted of this study varied from $1.29 \%$ to $2.02 \%$. This resulted in accordance with the standard and both of the control. The lowest ash content obtained on the fishball with $0.25 \%$ carrageenan from 40 days ages and it was a significant difference $(\mathrm{p}<0.05)$ compared to $0.5 \%$ of the same ages and 45 days ages on both of concentration.

The protein content of the fishball resulted ranged from $13.40 \%$ to $15.23 \%$. The highest protein content obtained on the fishball with $0.25 \%$ carrageenan from 50 days ages and it was a significant difference to other treatment $(\mathrm{p}<0.05)$ and higher than fishball with STPP $0.5 \%$. The fat content of this result showed that the fishball with carrageenan from 40 days ages was not significant differences with 45 days ages, but a significant difference with 50 days ages $(p<0.05)$. The fat content result of this study showed varied from $0.22 \%$ to $0.55 \%$.

The carbohydrate content of these samples ranged from $2.30 \%$ to $4.42 \%$ and there were significantly different $(\mathrm{p}<0.05)$ to the treatment.

Crude fiber content, sulfate content, and texture

Crude fiber content, sulfate content, and texture showed in Table 2. Its role in the promotion of health and disease risk reduction such cardiovascular

Table 1: Proximate analysis of fishball samples

\begin{tabular}{|c|c|c|c|c|c|c|}
\hline Harvest time (days) & Concentration of carrageenan (\%) & Moisture (\%) & Ash (\%) & Protein (\%) & Fat $(\%)$ & Carbohydrate (\%) \\
\hline \multirow[t]{2}{*}{40} & 0.25 & $77.89^{c}$ & $1.29^{\mathrm{a}}$ & $14.51^{\mathrm{b}}$ & $0.27^{\mathrm{a}}$ & $2.30^{\mathrm{a}}$ \\
\hline & 0.50 & $75.66^{\mathrm{a}}$ & $1.79^{\mathrm{b}, \mathrm{c}}$ & $14.15^{b}$ & $0.25^{\mathrm{a}}$ & $3.60^{c}$ \\
\hline \multirow[t]{2}{*}{45} & 0.25 & $77.74^{\mathrm{c}}$ & $2.02^{\mathrm{c}}$ & $13.40^{\mathrm{a}}$ & $0.22^{\mathrm{a}}$ & $2.76^{\mathrm{a}, \mathrm{b}}$ \\
\hline & 0.50 & $77.36^{c}$ & $1.79^{\mathrm{b}, \mathrm{c}}$ & $13.48^{\mathrm{a}}$ & $0.23^{\mathrm{a}}$ & $4.42^{c}$ \\
\hline \multirow[t]{2}{*}{50} & 0.25 & $76.41^{\mathrm{b}}$ & $1.64^{\mathrm{a}, \mathrm{b}}$ & $15.23^{c}$ & $0.48^{\mathrm{b}}$ & $4.11^{\mathrm{c}}$ \\
\hline & 0.50 & $76.51^{\mathrm{b}}$ & $1.62^{\mathrm{a}, \mathrm{b}}$ & $14.22^{\mathrm{b}}$ & $0.55^{b}$ & $3.18^{\mathrm{b}, \mathrm{c}}$ \\
\hline Without carrageenan & & 77.56 & 1.87 & 12.60 & 0.17 & 5.22 \\
\hline $\mathrm{SNI}^{1}$ & & Max 65 & 2.0 & Min. 7 & - & - \\
\hline
\end{tabular}

${ }^{1}$ Suggested value for fishball based on Indonesian National Standard (SNI 7266:2014) by BSN (2014). Values within a column followed by different letters are significantly different $(\mathrm{p}<0.05)$ according to the Duncan's test

Table 2: Crude fiber content, sulfate content, and texture of fishball samples

\begin{tabular}{lllll}
\hline Harvest time (days) & Concentration of carrageenan (\%) & Crude fiber (\%) & Sulfate (\%) & Texture (n) \\
\hline 40 & 0.25 & $4.61^{\mathrm{d}}$ & $3.27^{\mathrm{c}, \mathrm{d}}$ & $1.15^{\mathrm{a}}$ \\
& 0.50 & $1.41^{\mathrm{a}}$ & $3.77^{\mathrm{b}, \mathrm{c}}$ & $1.18^{\mathrm{a}}$ \\
45 & 0.25 & $4.74^{\mathrm{d}}$ & $2.59^{\mathrm{a}}$ & $1.41^{\mathrm{a}}$ \\
& 0.50 & $3.58^{\mathrm{c}}$ & $3.43^{\mathrm{d}}$ & $1.21^{\mathrm{a}}$ \\
50 & 0.25 & $2.98^{\mathrm{b}}$ & $3.00^{\mathrm{b}, \mathrm{c}}$ & $1.28^{\mathrm{a}}$ \\
& 0.50 & $3.79^{\mathrm{d}}$ & $2.75^{\mathrm{a}, \mathrm{b}}$ & $1.24^{\mathrm{a}}$ \\
Without carrageenan & & 2.84 & 3.72 & 0.74 \\
STPP 0.5\% & & 2.45 & 1.79 \\
\hline
\end{tabular}

Values within a column followed by different letters are significantly different $(\mathrm{p}<0.05)$ according to the Duncan's test 
disease and cancer [17]. Crude fiber consists largely of cellulose (60-80\%), lignin (4-6\%), and some mineral matter [18]. The result showed that there were significant different $(\mathrm{p}<0.05)$ on $0.5 \%$ carrageenan harvested from all seaweed ages, while the fishball with adding $0.25 \%$ carrageenan from 40 and 45 ages was not significant ( $p>0.05$ ).

\section{Water activity (Aw)}

The water activity of this result showed varied $0.87-0.91$ and there were significant differences $(p<0.05)$ among treatments (Fig. 1). Aw value is used to free or available water in the food system [19]

\section{Color}

The color of fishballs samples Table 3 showed that there were significant differences $(\mathrm{p}<0.05)$ on $\mathrm{L}^{*}$ and $\mathrm{b}^{*}$ value, while $\mathrm{a}^{*}$ value showed that there were no significant differences $(p>0.05)$. The $L^{*}$ value of the samples ranged from 63.27 to 66.47 , the $\mathrm{a}^{*}$ value ranged from 2.08 to 2.30 , and $b^{*}$ value ranged from 3.59 to 4.44 .

\section{DISCUSSION}

The moisture content from the result of this study showed a higher than the Indonesian standard. The control samples (fishball without carrageenan and fishball added STPP) also showed higher moisture compared to the Indonesian standard. This resulted also showed a higher compared to Kurniasari et al. [20] that varied from $63.53 \%$ to $66.60 \%$ water content of fishball added $0.3 \%$ STPP. This result was mainly because of the different formulas used in the process to each other. The quality of fresh fish can also effect of moisture content. The fishball without carrageenan addition showed the lower content $(12.60 \%)$. The protein content of this fishball showed that the result in accordance with the standard (min. 7\%) [21,22].

The fat content in this sample was affected; many factors such as the material of fishballs were used in the process. Carrageenan is one of polysaccharides also has a function as a fat reducer. The blend of many ingredients containing carrageenan can be used to offset the

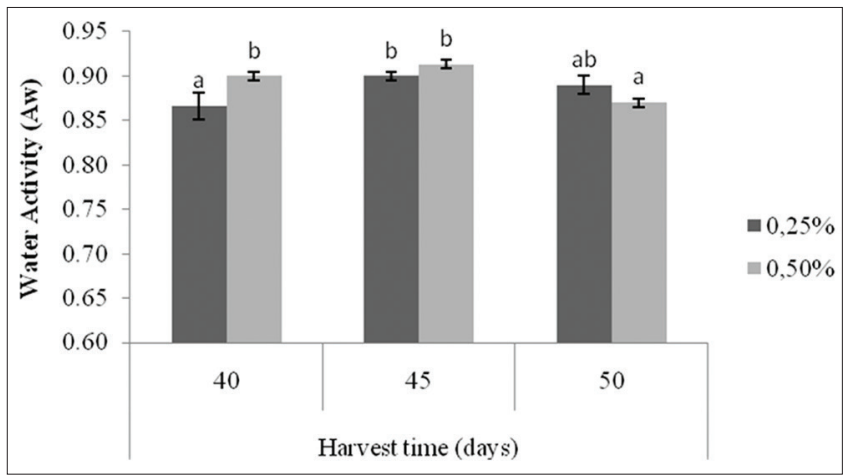

Fig. 1: Water activity of fishball samples. Bars within different letters are significantly different $(p<0.05)$ according to the Duncan's test.

Table 3: The color of fishball samples

\begin{tabular}{lllll}
\hline Harvest time (days) & $\begin{array}{l}\text { Concentration of } \\
\text { carrageenan (\%) }\end{array}$ & $\mathbf{L}^{*}$ & $\mathbf{a}^{*}$ & $\mathbf{b}^{*}$ \\
\hline 40 & 0.25 & $63.90^{\mathrm{a}, \mathrm{b}}$ & $2.10^{\mathrm{a}}$ & $4.09^{\mathrm{b}}$ \\
& 0.50 & $65.27^{\mathrm{b}, \mathrm{c}}$ & $2.20^{\mathrm{a}}$ & $3.64^{\mathrm{a}}$ \\
45 & 0.25 & $66.47^{\mathrm{c}}$ & $2.21^{\mathrm{a}}$ & $4.15^{\mathrm{b}}$ \\
& 0.50 & $63.70^{\mathrm{a}, \mathrm{b}}$ & $2.08^{\mathrm{a}}$ & $4.26^{\mathrm{b}}$ \\
50 & 0.25 & $63.27^{\mathrm{a}}$ & $2.30^{\mathrm{a}}$ & $3.59^{\mathrm{a}}$ \\
& 0.50 & $65.99^{\mathrm{c}}$ & $2.28^{\mathrm{a}}$ & $4.44^{\mathrm{b}}$ \\
Without carrageenan & & 68.58 & 2.35 & 4.20 \\
STPP 0.5\% & & 69.14 & 2.24 & 5.15 \\
\hline
\end{tabular}

Values within a column followed by different letters are significantly different $(\mathrm{p}<0.05)$ according to the Duncan's test poor quality associated with low-fat, such as beef-burger, meatballs, or sausage [23]. The carbohydrate content in these fishballs might be derived from tapioca flour. Raw fish was used in this product, in general, has low amounts of carbohydrate in their muscle [24].

The sulfate content of foods is one of the important composition because of its function in human metabolism. Sulfate may be important for effect on the requirement for methionine and cysteine, the effect on the large bowel metabolism to reduce a substance potentially toxic [25]. The sulfate content of this result varied from $2.59 \%$ to $3.77 \%$. The lowest content of sulfate obtained on the fishball added $0.25 \%$ carrageenan cultivated from 45 days ages. While the highest level of sulfate was in fishball, it added $0.5 \%$ carrageenan harvested in 40 days ages. The sulfate content data showed that there were different significant $(p<0.05)$ to the treatment. Sulfate content also was one of the important properties in the manufacturing carrageenan. The longer harvest time may affect the sulfate level decreased [26].

The texture level of this fishball resulted varied from $1.15 \mathrm{~N}$ to $1.41 \mathrm{~N}$ and there were no significant differences ( $p>0.05)$. The texture level of this sample was lower than the fishball adding STPP $0.5 \%$ and higher than the samples without carrageenan. The carrageenan adding on fishball showed a different level of texture than without carrageenan. This result also accordance with [19] reported that carrageenan samples on fishballs had the highest of texture parameters.

The crude fiber content of this study varied from $1.41 \%$ to $4.79 \%$. The highest fiber obtained in the sample with $0.5 \%$ carrageenan harvested from 50 days ages. This result was mainly because of crude fiber in carrageenan obtained; the longest ages have more crude fiber containing. The increasing concentration of carrageenan may cause the level of crude fiber increased.

Aw is the amount of free water in the product which available to grow of microorganism. A low Aw value will prevent microbial growth, especially mold [27]. Aw level of the fishballs adding carrageenan lower than compared to the fishballs without carrageenan (0.93). It indicated that the carrageenan had the ability to bind free water.

The differences of ash content may be caused by the ash content of the carrageenan from the various harvest time. Asikin and Kusumaningrum [8] reported that the ash of carrageenan from the different harvest time affected by the water quality of the seaweed cultivated. The $\mathrm{L}^{*}$ value and $\mathrm{a}^{*}$ value of the fishball with carrageenan lower than compared to the fishball without carrageenan and STPP. The addition of carrageenan decreases the lightness intensity of fishballs. Color is known to be important for a food product as it usually affects consumer preferences. The lighter fishballs are perceived to be fresh and have better quality for fish-based products [28].

\section{CONCLUSIONS}

The fishballs adding $0.25 \%$ and $0.50 \%$ carrageenan from various harvest times showed that some of the proximate, crude fiber, sulfate, $L^{*}$, and $b^{*}$ were significantly different $(p<0.05)$. While the texture and $a^{*}$ were not significantly different for all treatments. Overall, the fishball by adding $0.25 \%$ carrageenan from 50 days ages of seaweed was determined as the best treatment based on the highest protein content and the lowest water activity.

\section{ACKNOWLEDGMENTS}

This research was funded by Project Implementation Unit Development of Four Higher Education Institution Project Islamic Development Bank, University of Mulawarman, grant number 137/UN17.11/PL/2019.

\section{AUTHORS' CONTRIBUTIONS}

All authors have read and agree to the published version of the manuscript. A.N.A. conceived and designed the experiments; I.K. analyzed the data and writing the manuscript. 


\section{CONFLICTS OF INTEREST}

The authors declare no conflicts of interest.

\section{REFERENCES}

1. Necas J, Bartosikova L. Carrageenan: A review. Vet Med 2013;58:187-205.

2. Van de Velde F, Lourenco ND, Pinheiro HM, Bakkered M. Carrageenan: A food-grade and biocompatible support for immobilisation techniques. Adv Synth Catal 2002;344:815-35.

3. Subaryono S. Carrageenan oligosaccharides: Biological activity and its development opportunities in Indonesia. Squalen Bull Mar Fish Postharvest Biotechnol 2018;13:35-43.

4. Azevedo G, Torres MD, Sousa-Pinto I, Hilliou L. Effect of preextraction alkali treatment on the chemical structure and gelling properties of extracted hybrid carrageenan from Chondrus crispus and ahnfeltiopsis devoniensis. Food Hydrocoll 2015;50:150-158.

5. Awang B, Anisuzzaman SM, Ding OW. Effect of process conditions on the gel viscosity and gel strength of semi-refined carrageenan (SRC) produced from seaweed (Kappaphycus alvarezii). J King Saud Univ Eng Sci 2014;26:3-9.

6. Pereira L. Population studies and carrageenan properties in eight gigartinales (Rhodophyta) from Western Coast of Portugal. Carbohydr Polym 2011;84:614-23.

7. Mochtar A, Parawansa I, Ali M, Jusoff K, Reta R, Astuti SD, et al. Effects of harvest age of seaweed on carragenan yield and gel strength. World Appl Sci J 2013;26:13-6.

8. Asikin AN, Kusumaningrum I. Physicochemical characteristics of carrageenan based on different harvesting times from Bontang Coastal, East Kalimantan. J Indones Fish Prod Proc 2019;22:136-42.

9. Ayadi MA, Kechaou A, Makni I, Attia H. Influence of carrageenan addition on turkey meat sausages properties. J Food Eng 2009;93:278-83.

10. Sarteshnizi RA, Hosseini H, Khaneghah AM, Karimi N. A review on application of hydrocolloids in meat and poultry products. Int Food Res J 2015;22:872-87

11. Cierach M, Kapitula MM, Szacilo K. The influence of carrageenan on the properties of low-fat frankfurters. Maet Sci 2009;82:295-9.

12. Volpe M, Coccia E, Siano F, Stasio M, Paolucco M. Rapid evaluation methods for quality of trout (Oncorhynchus mykiss) fresh fillet preserved in an active edible coating. Foods 2019;8:1-18.

13. Asikin AN, Kusumaningrum I, Sutono D. Extraction and characterization of functional properties of carrageenan Kappaphycus alvarezii from coast of East Kutai district. J Sci Technol Trip Mar 2019;7:49-58.

14. AOAC. Official Methods of Analysis of the Association of Official Analytical Chemists International. $18^{\text {th }}$ ed. Washington DC: AOAC; 2005.
15. Apriyantono D. Food Analysis Laboratory Instructions. Bogor, Indonesia: Ministry of Education and Culture, Directorate General of Higher Education, Inter-University Center for Food and Nutrition Institute of Agriculture Bogor; 1989.

16. Badan Standardisasi Nasional. Indonesian National Standard No. 7266. Jakarta, Indonesia: Badan Standardisasi Nasional; 2014.

17. Selvakumaru U, Amutha K. Investigation investigation and efficacy on protein hydrolysate of Pila globosa (a fresh water molluscs) in various biomedical aspects. Asian J Pharm Clin Res 2016;9:277-81.

18. Madhu C, Krishna KM, Reddy KR, Lakshmi PJ, Kelari EK. Estimation of crude fibre content from natural food stuffs and its laxative activity induced in rats. Int J Pharma Res Health Sci 2017;5:1703-6.

19. Huang H, Clarke AD. Performances of cold-set binders, food hydrocolloids, and commercial meat binder on the physical and chemical characteristics of tilapia fish balls. Int J Anim Sci 2017;1:1-9.

20. Kurniasari RY, Affandi DR, Sanjaya AP. Textural and sensory properties of little tuna fish balls (Euthynnus affinis) arrowroot flour substitutions (Maranta arundinacea Linn.) added with sodium tripolyphosphate. In: International Conference on Food Science and Engineering. Indonesia: IOP Publishing; 2019. pp. 1-6.

21. Prabha J, Vincent S, Joseph S, Magdalane J. Bioactive and functional properties of fish protein hydrolisate from leiognathus bindus. Asian J Pharm Clin Res 2016;9:277-81.

22. Nurjanah, Suseno SH, Hidayat T, Pramudhita P, Ekawati Y, Arifianto TB. Change in nutrional compostion of skipjack Katsuwonus pelamis due to frying process. Int. Food Research Journal 2015;22:2093-102.

23. Duran A, Ozbas OO. Production of low-fat high-fiber meatballs. J Sci Eng Res 2018;5:150-5.

24. Duman M, Peksezer B. Quality changes of fish balls prepared from of mosul bleak (Alburnus mossulensis) stored at $-18^{\circ} \mathrm{C}$ under air or vacuum. Ege J Fish Aquat Sci 2016;33:285-90.

25. Florin, Timothy HJ, Neale G, Goretski S, et al. The sulfate content of foods and beverages. J Food Composition Anal 1993;6:140-51.

26. Wenno MR, Thenu JL, Lopulalan CG. Characteristics of kappa carrageenan from Kappaphycus alvarezii at different harvesting times. J Postharvest Biotechnol Mar Fish 2012;7:61-68

27. Pratama Y, Abduh SB, Legowo AM, Pramono YB, Albaarri AN. Optimum carrageenan concentration improved the physical properties of cabinet-dried yoghurt powder. In: International Symposium on Food and Agro-biodiversity (ISFA). Indonesia: IOP Publishing; 2017. p. 1-7.

28. Tee ET, Siow LF. Effect of tapioca and potato starch on the physical properties of frozen spanish mackerel (Scomberomorus guttatus) fish balls. Int Food Res J 2017;241:182-190. 